\title{
ЛАНДШАФТОСФЕРА ВЗГЛЯДОМ ЛАНДШАФТНОЙ ГЕОГРАФИИ
}

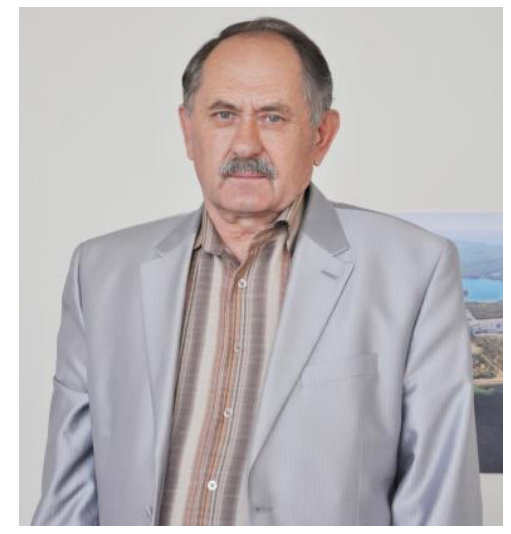

границе взаимодействия слоёв литосферы, гидросферы и атмосферы. Последние наиболее интенсивно взаимодействуют в ландшафтной сфере, названной Ф.И. Мильковым биологическим фокусом Земли. Сам же термин ландшафтная сфера был предложен Ю.К. Ефремовым в 1950 году. Ландшафтная сфера - это узкая часть географической оболочки, то есть та её часть, на сохранении свойств которой акцентируется внимание при решении локальных и региональных природопользовательских задач.

Ландшафтная сфера рассматривается как сложная пространственно-временная динамическая система элементов неорганической и органической природы, возникающая в результате взаимопроникновения, взаимообусловленности и взаимодействии различных геосфер. Она представляет собой слой сравнительно небольшой толщины, равной вертикальной мощности ландшафтов. Она прерывиста, т. к. приурочена только к суши (континентальной и островной). Структурными элементами этой сферы являются ландшафты.

Ландшафтная сфера занимает особое положение в классификационном ряду ландшафтов. Сама является важным классификационным инструментом по обобщению материалов при классификации ландшафтных геосистем и представляется важным объектом практической реализации ландшафтного подхода (метода) в решении различных производственных и научных вопросов. При этом сущность ландшафтного подхода определяется:

во-первых, в учёте индивидуальности природы земной поверхности, организованной в сочетании природнотерриториальных комплексов (геосистем), образующих относительно однородные по генезису территории, называемые ландшафтами;

во-вторых, в учёте их пространственно-временной иерархической структуры;

в-третьих, причинно-следственных взаимосвязей между отдельными компонентами.

То есть, ландшафтному анализу подвергаются ландшафтные геосистемы различных рангов и, в конечном итоге, даётся та или иная географическая практическая оценка соответствующего географического пространства ландшафтной сферы. Полученные результаты анализа, синтеза и оценки можно применить для решения соответствующих производственно-хозяйственных задач вплоть до ландшафтов ранга ландшафтной сферы.

В ландшафтной сфере выделяются региональные ландшафтные пояса, зоны, страны, области и другие таксоны типологического регионального ряда по А.Г. Исаченко (1991). Что касается ландшафтных поясов, то в ландшафтных классификациях поясов выделяются широтные пояса важные при изучении слабо освоенных территорий, каковой является территория Тихоокеанской России.

В трудах, нацеленных на оптимизацию освоения территорий ландшафтной сферы, на практическую реализацию ландшафтного подхода в решении производственных задач, рассматриваются результаты авторских геолого-географических и географических 
исследований в окраинно-континентальной зоне контакта континента и северо-восточной части Тихого океана. Выделяются в ландшафтной сфере окраинно-континентальные и внутриконтинентальные азональные ландшафтные пояса.

Несмотря на значимость знаний о ландшафтной сфере и её составляющих разнообразных ландшафтных геосистем, в том числе при освоении территорий, таких как территория России, ландшафтной тематики и картографированию ландшафтов в последнее время посвящено ограниченное количество работ.

На основе углублённого покомпонентного анализа в последние годы разработана ландшафтная классификация, составлена базовая ландшафтная карта Приморского края M1: 500000 и легенда к ней, разработана в масштабе 1: 500000 ландшафтная классификация Сахалинской области, продолжаются ландшафтные исследования по другим территориям окраинноконтинентальной части Тихоокеанской России. Впервые показаны особенности формирования фундамента ландшафтов с опорой на изучение петрографического состава и структурно-тектоническое положение осадочных и других литокомплексов. Выявлены особенности структуры и организации ландшафтов, проведён системный анализ их размещения по территории с учётом пространственно-площадной горизонтальной и высотной дифференциации. Дана статистическая оценка пространственного распределения ландшафтов и их количественных параметров. В комплексном анализе антропогенных преобразований для целей обеспечения экологической безопасности природопользования использован ландшафтный подход и разрабатываемый нами метод ландшафтной индикации географического пространства.

На региональных примерах (в частности по СихотэАлинскому звену) в 2014 году был проведён анализ ландшафтных особенностей по группам ландшафтных, пространственных и морфологических данных и установлены статистические количественные особенности ландшафтов. Анализируя полученные данные по отмеченным выше характеристикам ландшафтных геосистем на основе конкретных статистических данных, например, по удалённости от морских акваторий, мы пришли к выводу, что рассматриваемые в работе геосистемы относятся по ландшафтной континентально-океанической дихотомии (Безруков, 2008) к особым, ранее в ландшафтной географии Тихоокеанской России и ландшафтной сфере не выделяемым, окраинно-континентальным геосистемам. Предлагается ландшафтные геосистемы обрамления Тихого океана рассматривать и выделять их как окраинно-континентальные ландшафтные геосистемы Тихоокеанского окраинноконтинентального ландшафтного пояса Тихоокеанской России.

Подчеркнём, что ландшафтные геосистемы пояса отличаются от других ландшафтных структур России не только пространственным, но и морфологическими характеристиками: по крутизне склонов, по горизонтальному и вертикальному их расчленению и пр. Все особенности геосистем дают основание выделять особый ландшафтный пояс Тихоокеанской России и назвать его Тихоокеанским окраинно-континентальным ландшафтным поясом. Он включает ландшафтные окраинноконтинентальные региональные звенья: Чукотское, Анадырьское, Корякское, Приохотское, Нижнеамурское, Сихотэ-Алинское, Камчатское и Сахалинское.

Проведённые исследования, базирующиеся на картографировании ландшафтов и их структур, оценке данных по изменению свойств ландшафтов и их пространственноплощадному распространению, рассматриваются как базовые для комплексной оценки антропогенных преобразований природной среды, оптимизации природопользования, конструктивного начала в обеспечении экологической безопасности природопользования рассматриваемых территорий. Они могут служить основой многоцелевых естественнонаучных и прогнозно-экономических исследований, в т. ч. при разработке концепций устойчивого развития регионов ландшафтной сферы, а также в подготовки специалистов-географов и других специальностей. 
Мною опубликовано около 200 научных работ, из них 24 монографии, 18 учебных пособий, издано 6 карт. В Национальном цифровом ресурсе Руконт опубликовано 33 работы (статьи, монографии, курсы лекций, карты и др.). Ряд учебных пособий имеют гриф учебно-методического объединения.

Исследования характеризуются высокой практической значимостью, которая определяется многоцелевым использованием результатов. Полученные данные применимы для экологических обоснований; палеогеографических, геологических реконструкций; регламентирования природопользования; проектирования строительства; прогноза природной обстановки и чрезвычайных ситуаций. Они используются государственными органами, в частности - Федеральными агентствами водных ресурсов и по недропользованию, а также научными и производственными организациями биолого-почвенного, географического, геологического, геохимического и экологического профилей.

По ряду учебных пособий и учебно-методическим комплексам получены Свидетельства об отраслевой регистрации разработок в Фонде алгоритмов и программ. Результаты научных исследований используются как справочный материал и как пособия для практических работ и дипломных проектов. Монография «Ландшафтная география Приморья (региональнокомпонентная специфика и пространственный анализ геосистем)» представляет собой «научное достижение Дальневосточного федерального университета и может служить образцом фундаментального исследования географической среды юга Дальнего Востока России».

По результатам многолетних авторских научных и практических исследований в сфере геолого-географического изучения и ландшафтного картографирования крупных региональных Приморского и Сахалинского звеньев окраинноконтинентального ландшафтного пояса Тихоокеанской России издан курс лекций в трёх томах «Ландшафтная география Приморского края Тихоокеанской России».
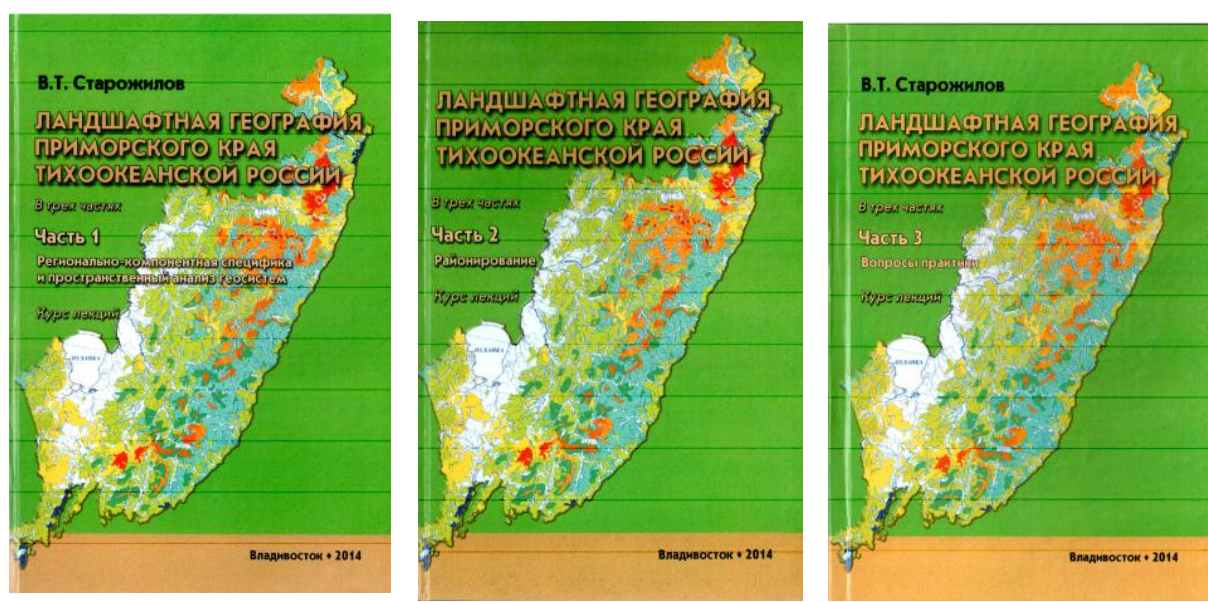

Особо отметим практическую направленность курса лекций. В третьем томе курса лекций «Ландшафтная география Приморского края Тихоокеанской России (вопросы практики)» рассмотрены вопросы практической реализации ландшафтного подхода в областях промышленного освоения, индикации денудации, химических и механических изменений компонентов ландшафтов, при организации новых аграрных предприятий, для создания продовольственной базы в горно-таежных ландшафтах, для туризма и рекреации, строительства, лесопользовании, планирования и проектирования вариантов природопользования и др.

В лекциях отмечается, что без базовой структурной модели многие динамические и другие модели будут недостаточно объективно отражать реальную природную ситуацию. Поэтому, прежде чем приступать к объективным многопрофильным оценкам, и в том числе динамики, функционированию географического пространства, необходимо, прежде всего, иметь базовую модель ландшафтной геосистемы территории. Такой моделью, рассматриваемой в рамках ландшафтной географии, 
представляется в качестве примера ландшафтная модель геосистемы Приморья. При этом под базовой моделью геосистемы понимается структурная ландшафтная геосистема, построенная на ландшафтном синтезе, основой которого является морфология ландшафта. В качестве такой базовой модели геосистемы рассматривается ландшафтная геосистема, зафиксированная на среднемасштабных и других ландшафтных картах в рамках ландшафтной географии Приморья.

Курс лекций «Ландшафтная география Приморская края Тихоокеанской России» на 18-й Дальневосточной книжной выставке-ярмарке «Печатный двор - 2015» удостоен дипломом «Лучшая учебная книга». Это же издание отмечено дипломом Дальневосточного регионального учебно-методического центра (ДВ РУМЦ) «За высокий уровень курса лекций», а также дипломом конкурса изданий высших учебных заведений «Университетская книга».
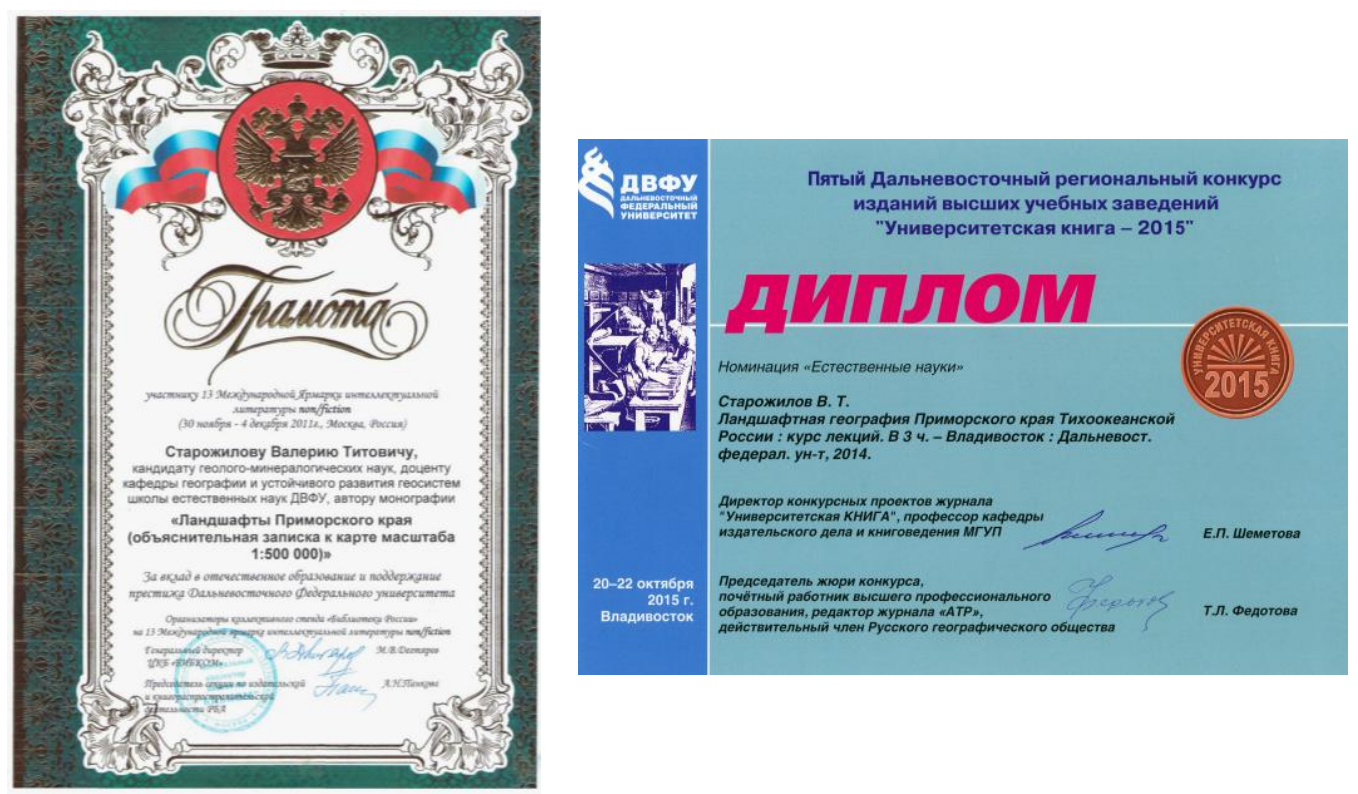

При последовательных исследованиях ландшафтная модель геосистем Сахалинской области и Приморского края и других может стать основой многоступенчатого, многоотраслевого и многоцелевого использования, стратегического планирования и управления территориями Сахалинской области и Приморского края, может быть использована при освоении Тихоокеанского окраинно-континентального ландшафтного пояса и других территорий, при выборе и создании зон приоритетного развития.
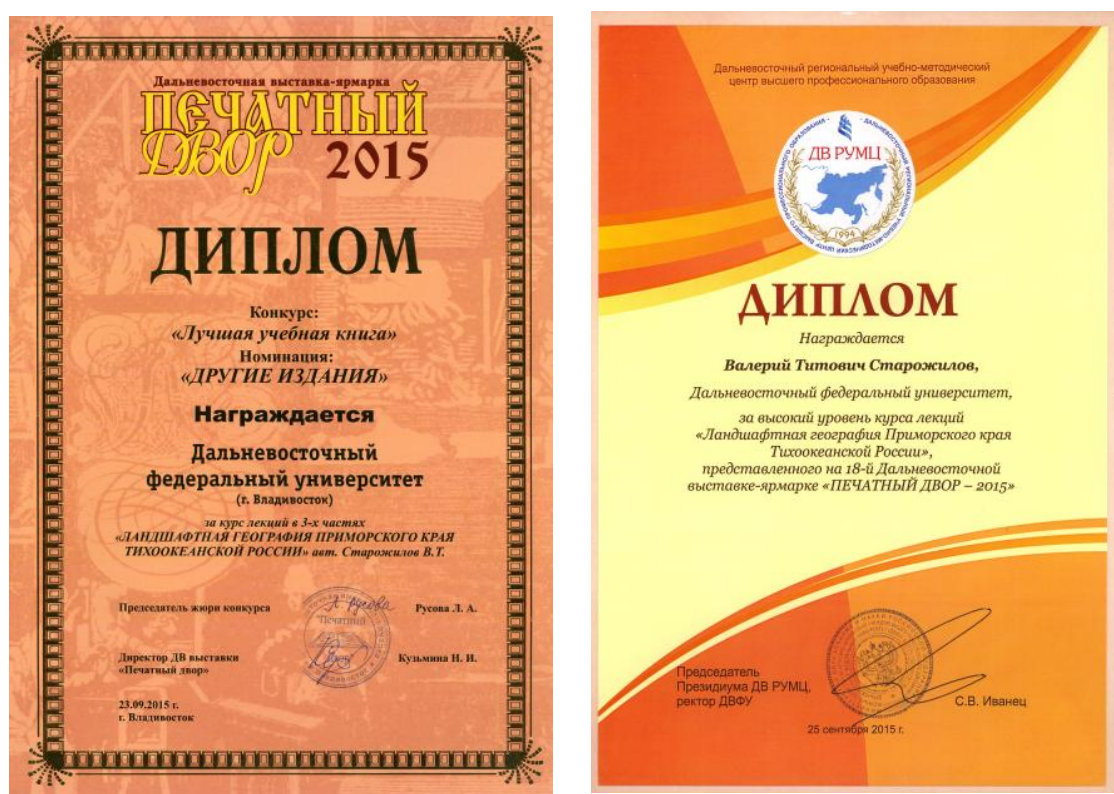

https://www.dvfu.ru/library/almanac-power-books-/ 